\title{
A Study on the Stability of $\alpha$-Cyanobenzyl Ester-type Pyrethroids in Mineral Carriers in the Presence of Malathion
}

\author{
Yasuyuki Katayama, Fumio Horide and Kozo Tsuji \\ Pesticides Research Laboratory, Takarazuka Research Center, \\ Sumitomo Chemical Co., Ltd., Konohana-ku, Osaka 554, Japan
}

(Received September 5, 1988)

\begin{abstract}
The stability of various pyrethroids in mineral carriers was studied in the presence or absence of malathion. All the pyrethroids studied were stable in mineral carriers in the absence of malathion. The pyrethroids having a cyano group in their alcohol moiety were significantly unstable in the presence of malathion, while the pyrethroids having no cyano group in their alcohol moiety were stable even in the presence of malathion. The decomposition seems to be caused by the reaction between the cyano group and some acidic, though unidentified, materials formed by the degradation of malathion in the mineral carriers. The results of mass, ${ }^{1} \mathrm{H}$ NMR, and IR spectra suggested that the decomposition product was formed through the conversion of a cyano group to a (methylthio)carbonyl group. Some kinds of alkali or alkaline earth metal salts of weak acids, such as calcium carbonate, calcium acetate, sodium phosphate acted as stabilizers for these pyrethroids in the presence of malathion without having any significant effect on the stability of malathion.
\end{abstract}

\section{INTRODUCTION}

Since invented, ${ }^{1)}$ photostable pyrethroids have been used as agricultural insecticides against a wide range of insect pests. Organophosphorus pesticides ${ }^{2)}$ have also been used for the same purpose, and in some cases they are combined with pyrethroids to widen the range of insecticidal spectrum..$^{3,4)}$ But then, a problem of compatibility among active ingredients occurs.

This report describes the compatibility of pyrethroids and malathion, which was chosen from organophosphorus pesticides for its remarkable ability to decompose some pyrethroids in mineral carriers, and discusses a decomposition mechanism of some pyrethroids. In order to improve the compatibility of pyrethroids and malathion, a stabilization method is also determined.

\section{EXPERIMENTAL}

\section{Materials}

All pesticides used in this study were syn- thesized in the Organic Synthesis Section, Pesticides Research Laboratory, Sumitomo Chemical Co., Ltd. Their chemical structures are shown in Fig. 1.

All alkaline salts were from Wako Pure Chemical Co., Ltd. and of reagent grade.

\section{Methods}

\subsection{Preparation of samples}

Samples were prepared according to the following composition.

\begin{tabular}{lc}
\hline & Content $(\% \mathrm{w} / \mathrm{w})$ \\
\hline Pyrethroid & 3.0 \\
Malathion & 30.0 \\
Stabilizer ${ }^{2}$ & 0.0 or 5.0 \\
Synthetic hydrated & 30.0 \\
silicone dioxide & Balance \\
\hline Kaolinite clay & 100.0 \\
\hline
\end{tabular}

a) Alkali or alkaline earth metal salts (Wako Pure Chemical Co., Ltd.).

\subsection{Storage stability test}

The samples were packed in polyethylene- 
Table 1 GC conditions for the analysis of pyrethroids and malathion.

\begin{tabular}{llll}
\hline & \multicolumn{1}{c}{ Pyrethroids group A ${ }^{\mathrm{a})}$} & \multicolumn{1}{c}{ Pyrethroids group $\mathrm{B}^{\mathrm{b})}$} & \multicolumn{1}{c}{ Malathion } \\
\hline Apparatus & Shimadzu GC-9A (FID) & Shimadzu GC-9A (FID) & Shimadzu GC-9A (FID) \\
Column & $2 \mathrm{~m} \times 3 \mathrm{~mm}$ (glass) & $1 \mathrm{~m} \times 3 \mathrm{~mm}$ (glass) & $1 \mathrm{~m} \times 3 \mathrm{~mm}$ (glass) \\
$\quad$ Liquid phase & $2 \%$ Dexsil 300GC & $3 \%$ Silicone OV-101 & $3 \%$ Silicone XE-60 \\
$\quad$ Support & Chromosorb W HP & Uniport HP & Chromosorb W (AW DMCS) \\
& $(80 / 100 \mathrm{mesh})$ & $(100 / 120 \mathrm{mesh})$ & $(60 / 80 \mathrm{mesh})$ \\
$\begin{array}{c}\text { Column temp. } \\
\text { Injection temp. }\end{array}$ & $250^{\circ} \mathrm{C}$ & $240^{\circ} \mathrm{C}$ & $170^{\circ} \mathrm{C}$ \\
$\begin{array}{c}\text { Nitrogen gas } \\
\quad \text { flow rate }\end{array}$ & $60 \mathrm{ml} / \mathrm{min}$ & $250^{\circ} \mathrm{C}$ & $190^{\circ} \mathrm{C}$ \\
$\begin{array}{c}\text { Internal } \\
\text { standard }\end{array}$ & Dioctylsebacate & $60 \mathrm{ml} / \mathrm{min}$ & $60 \mathrm{ml} / \mathrm{min}$ \\
\hline
\end{tabular}

a) Fenvalerate, fenpropathrin, phenothrin.

b) Cypermethrin, permethrin.
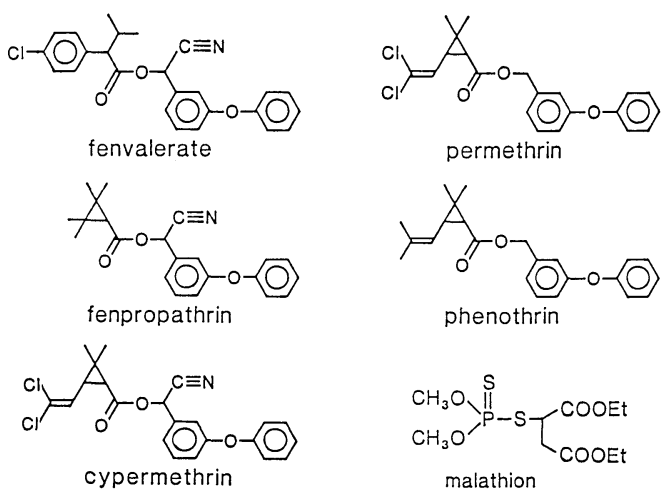

Fig. 1 Chemical structures of pyrethroids and malathion.

aluminum laminated bags and stored at $60^{\circ} \mathrm{C}$ for 30,40 or 50 days.

\subsection{Analysis of active ingredients}

The contents of active ingredients in the samples were analyzed by gas chromatography (GC) under the conditions in Table 1.

\subsection{Identification of decomposition products}

Decomposition products were identified by GC-Mass analysis (Hitachi DF/GC/MS: $20 \mathrm{eV}$ electrons, ion source at $180^{\circ} \mathrm{C}$ ) using a glass column $(2 \mathrm{~m} \times 3 \mathrm{~mm}, 2 \%$ Dexsil $300 \mathrm{GC}$ on Chromosorb W 80/100 mesh) and He gas as a carrier.

After pyrethroids had been completely decomposed while stored at $60^{\circ} \mathrm{C}$ for 60 days, the decomposition products were extracted with chloroform from samples and purified by thinlayer chromatography (TLC), by using pre- coated silica gel 60F-254 chromatoplates $(20 \mathrm{~cm} \times 20 \mathrm{~cm}, \quad 0.25 \mathrm{~mm}$ layer thickness, Merck) and $n$-hexane/ethyl acetate $(1 / 1)$ as a solvent system $(R f=0.67)$. Structures of the decomposition products were identified with ${ }^{1} \mathrm{H}$ NMR (Hitachi R-90H: $90 \mathrm{MHz}$, tetramethylsilane as an internal standard) and an IR (Hitachi 260-10) spectrometer.

\section{RESULTS AND DISCUSSION}

\section{Stability of Pyrethroids in Mineral Carriers}

Table 2 shows the stability of pyrethroids in mineral carriers with or without malathion. Although all the pyrethroids studied scarcely

Table 2 Stability of pyrethroids in a mineral carrier in the presence or absence of malathion.

\begin{tabular}{|c|c|c|c|}
\hline \multirow{3}{*}{ Pyrethroid } & & \multicolumn{2}{|c|}{$\begin{array}{c}\text { Decomposition percentage } \\
(\%)\end{array}$} \\
\hline & & \multicolumn{2}{|c|}{ Storage period $\left(\right.$ at $\left.60^{\circ} \mathrm{C}\right)$} \\
\hline & & 30 days & 40 days \\
\hline \multirow[t]{2}{*}{ Fenvalerate } & $\mathrm{A}$ & 0.5 & 4.5 \\
\hline & $\mathrm{P}$ & 37.8 & 77.9 \\
\hline \multirow[t]{2}{*}{ Fenpropathrin } & $\mathrm{A}$ & 0.3 & 1.0 \\
\hline & $\mathrm{P}$ & 39.3 & 69.1 \\
\hline \multirow[t]{2}{*}{ Cypermethrin } & $\mathrm{A}$ & 3.6 & 4.5 \\
\hline & $\mathrm{P}$ & 36.5 & 79.5 \\
\hline \multirow[t]{2}{*}{ Permethrin } & A & 0.4 & 3.1 \\
\hline & $\mathrm{P}$ & 3.2 & 4.5 \\
\hline \multirow[t]{2}{*}{ Phenothrin } & $\mathrm{A}$ & 2.6 & 5.2 \\
\hline & $\mathrm{P}$ & 3.8 & 6.8 \\
\hline
\end{tabular}

$\mathrm{A}$ : in the absence of malathion, $\mathrm{P}:$ in the presence of malathion. 
decomposed in the absence of malathion, some were unstable in the presence of malathion. The stability of pyrethroids in the presence of malathion seemed to depend on the chemical structure. That is, considerable decomposition was observed when the pyrethroids had a cyano group in their alcohol moiety, such as fenvalerate, fenpropathrin, and cypermethrin, while the pyrethroids without a cyano group, such as phenothrin and permethrin, were quite stable even in the presence of malathion. Either in the presence or in the absence of pyrethroids, malathion decomposed by 20 $30 \%$ after stored at $60^{\circ} \mathrm{C}$ for 30 days.

\section{Appearance of Decomposition Products}

The gas chromatograms of a mixture of fenvalerate and malathion before and after storage at $60^{\circ} \mathrm{C}$ for 30 days are shown in Fig. 2. The decomposition products showed peaks in the gas chromatogram only when the mixture was stored. In the cases of other $\alpha$-cyanopyrethroids, the decomposition products were detected corresponding to the ones in fenvalerate, but in the absence of malathion, they were not detected.

\section{Identification of the Decomposition Product}

Figure 3 shows mass spectra of fenvalerate and its decomposition products. Two spectra corresponding to the respective peaks of the decomposition products (Fig. 2) were exactly
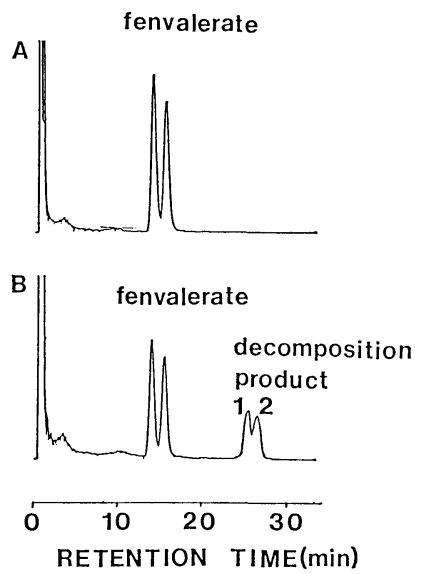

Fig. 2 Gas chromatogram of fenvalerate in a carrier containing malathion before (A) and after (B) storage at $60^{\circ} \mathrm{C}$ for 30 days. the same. This indicated that the two peaks of the decomposition products were due to diastereomers. The two spectra were both found to give a parent peak at $m / z=468$, which is 49 larger in mass number than that of fenvalerate.

Figures 4 and 5 show ${ }^{1} \mathrm{H}$ NMR and IR spectra of the decomposition products, though they were a mixture of diastereomers, as mentioned above. Because the spectrum patterns did not greatly differ, the decomposition products and fenvalerate were supposed to be similar in structure. The ${ }^{1} \mathrm{H}$ NMR spectrum of the decomposition products showed two peaks at about $6 \mathrm{ppm}$, which were supposed to come from two diastereomers as mentioned above, and these two peaks could be assigned to a proton at the $\alpha$-carbon of the benzyl ester site. The two peaks slightly shifted to a higher field than the corresponding peaks of fenvalerate. This shift seemed to be caused by the chemical modification of the cyano group in fenvalerate. There was another peak at near $2 \mathrm{ppm}$, which seemed to be due to a newly produced methyl ester group.

The IR spectrum of the decomposition
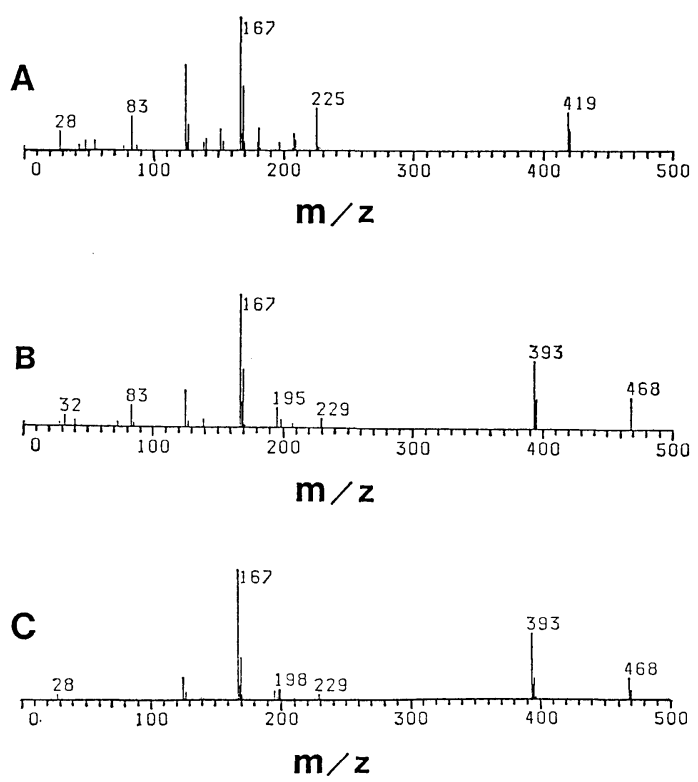

Fig. 3 Mass spectra of fenvalerate (A), decomposition product $1(\mathrm{~B})$ and decomposition product 2 (C).

Decomposition product 1 and 2: See Fig. 2. 


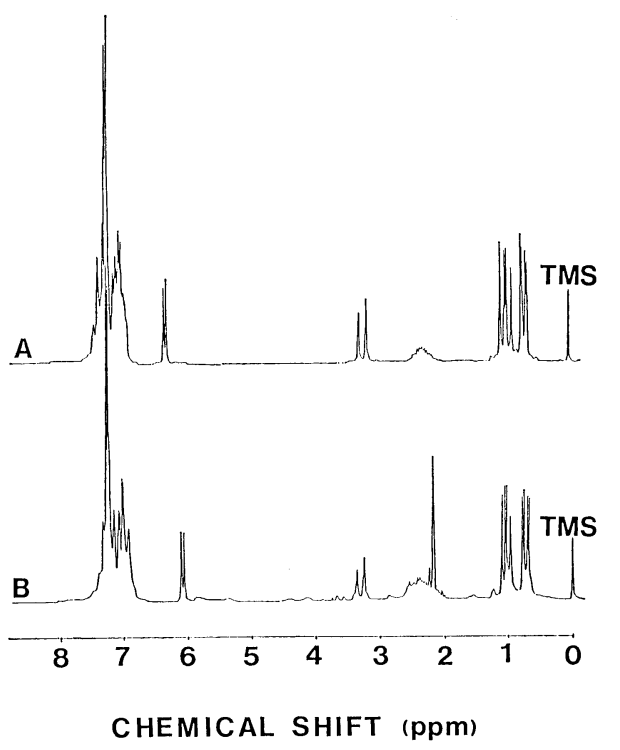

Fig. $4{ }^{1} \mathrm{H}$ NMR spectra of fenvalerate (A) and the decomposition product (B).

products gave two bands of $\mathrm{C}=\mathrm{O}$ stretching vibration $\left(1730\right.$, and $\left.1670 \mathrm{~cm}^{-1}\right)$, while that of fenvalerate gave only a single band of $\mathrm{C}=\mathrm{O}$ stretching vibration $\left(1740 \mathrm{~cm}^{-1}\right)$. This showed that the decomposition products contained another $\mathrm{C}=\mathrm{O}$ group besides the one at the benzyl ester site.

It is possible that the decomposition product, including two diastereomers, were formed by the conversion of the cyano group in

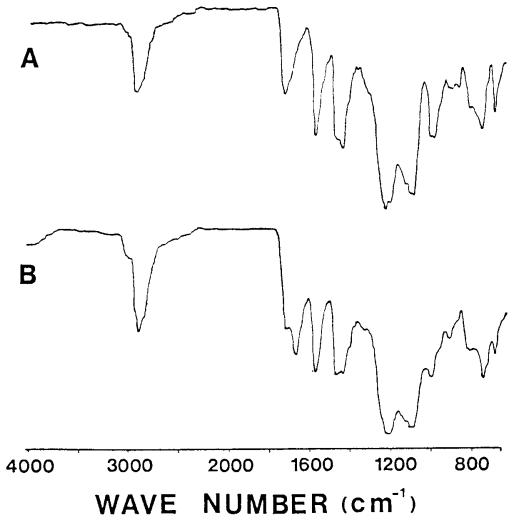

Fig. 5 IR spectra of fenvalerate (A) and the decomposition product (B).

fenvalerate to a (methylthio) carbonyl group, from the following observations:

1) The decomposition products and fenvalerate were similar in structure (Figs. 4 and 5).

2) The cyano group was converted to the functional group containing a $\mathrm{C}=\mathrm{O}$ group (Fig. $5)$.

3) The newly produced group was considered to have methyl protons of an ester, which gave a peak near $2 \mathrm{ppm}$ in the NMR spectrum (Fig. 4).

4) The mass number of the parent peak of the decomposition products was 49 larger than that of fenvalerate, equal to the mass number difference between (methylthio)carbonyl and cyano groups (Fig. 3).

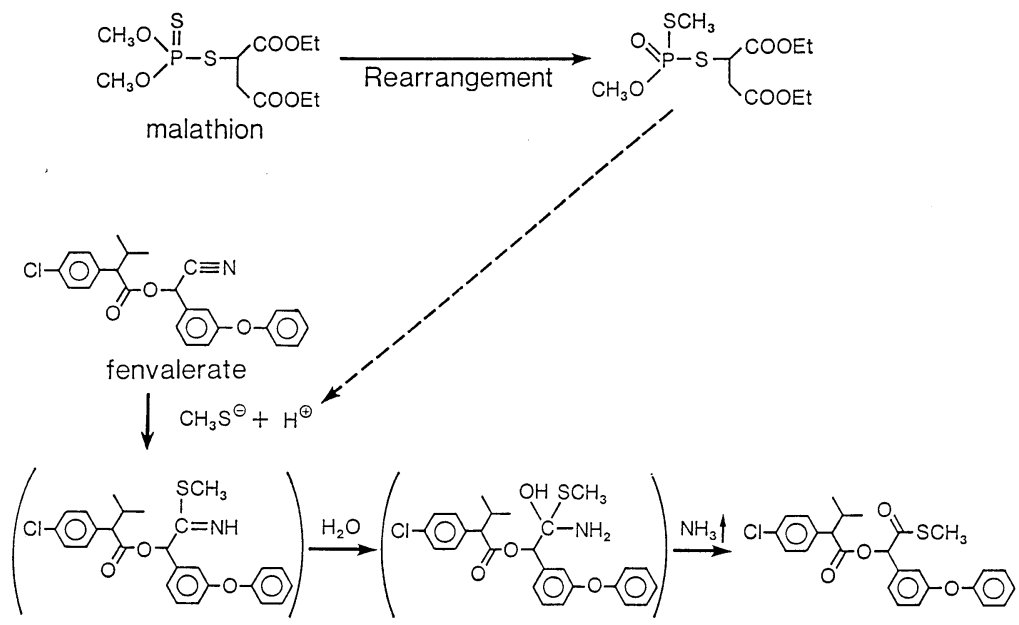

Fig. 6 A proposed decomposition mechanism of fenvalerate in the presence of malathion. 


\section{Decomposition Mechanism}

A decomposition mechanism of fenvalerate was supposed as shown in Fig. 6: First, a $S$-methyl derivative of malathion was produced by the thiono-thiolo rearrangement of malathion in mineral carriers. ${ }^{5,6}$ Then, the cyano group of pyrethroid was attacked by some acidic materials, probably methylthio anion formed by the degradation of the $S$-methyl derivative, and changed to an iminothio ether group. $^{7,8)}$ Finally, followed by the hydrolysis of the iminothio ether group, ${ }^{9}{ }^{9}$ a (methylthio)carbonyl derivative of fenvalerate was formed.

\section{Decomposition of Other $\alpha$-Cyano-pyrethroids}

The similar reaction to the one in the mixture of fenvalerate and malathion seemed to occur in a mixture of other $\alpha$-cyano-pyrethroids and malathion.

Table 3 shows the mass numbers of parent peaks of fenvalerate, fenpropathrin, cypermethrin and their decomposition products

Table 3 Mass numbers of parent peaks of pyrethroids and the decomposition products.

\begin{tabular}{lccc}
\hline & \multicolumn{4}{c}{ Mass number of parent peak } \\
\cline { 2 - 4 } Pyrethroid & $\begin{array}{c}\text { Pyrethroid } \\
(1)\end{array}$ & $\begin{array}{c}\text { Decomposi- } \\
\text { tion product }\end{array}$ & $(2)-(1)$ \\
\hline Fenvalerate & 419 & 468 & 49 \\
Fenpropathrin & 349 & 398 & 49 \\
Cypermethrin & 415 & 464 & 49 \\
\hline
\end{tabular}

formed in the presence of malathion. All the mass numbers of the parent peaks were 49 larger than that of each corresponding pyrethroid, indicating that cyano groups of the pyrethroids were converted to (methylthio)carbonyl groups in the presence of malathion.

\section{Stabilization of $\alpha$-Cyano-pyrethroids in Mineral Carriers}

The decomposition mechanism proposed suggests that an addition of any alkaline compounds into a carrier may effectively inhibit acidic materials from attacking the cyano group of pyrethroid. Furthermore, alkaline compounds are to be easily mixed with mineral carriers to form a solid formulation. Thus, alkali or alkaline earth metal salts of weak acid were tested for their capacity to stabilize pyrethroids having a cyano group in their alcohol moiety. ${ }^{10)}$

Figure 7 shows the decomposition percentages of fenvalerate and malathion after storage at $60^{\circ} \mathrm{C}$ for one month in $5 \%$ mineral carriers of various alkaline salts.

When no alkaline salt was added to the carriers, fenvalerate and malathion decomposed by $35 \%$ and $16 \%$ respectively.

In the presence of calcium hydroxide, magnesium oxide, and potassium carbonate, fenvalerate and malathion decomposed more significantly than in the absence of alkaline salts. Such strong alkaline salts seemed to promote the hydrolysis of malathion. They also seemed to have an effect on the hydrolysis

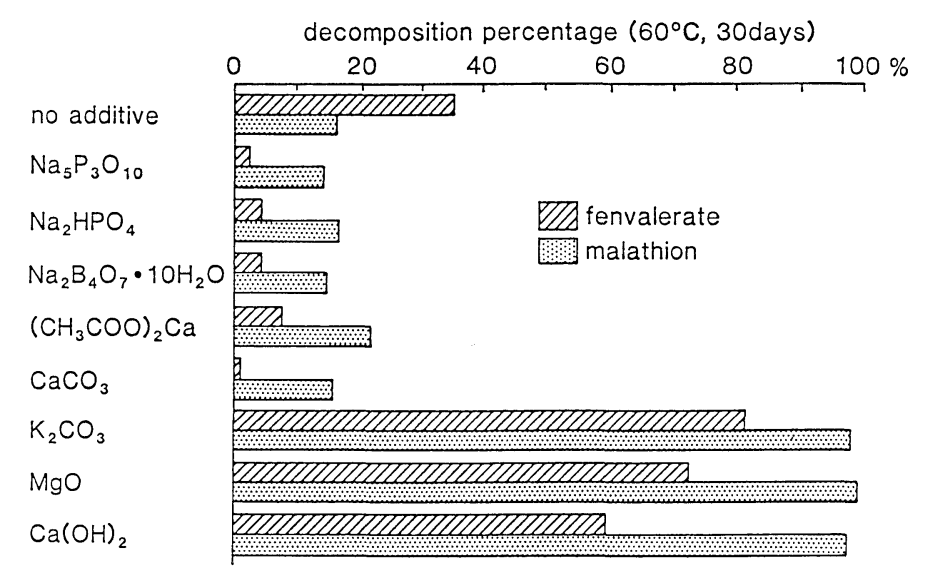

Fig. 7 Fenvalerate and malathion decompositions in 5\% carriers of alkaline salts. 
Table 4 Effects of alkaline salts on the stability of $\alpha$-cyano pyrethroids in the presence of malathion.

\begin{tabular}{lcccc}
\hline \multirow{2}{*}{ Additive } & \multicolumn{3}{c}{ Decomposition percentage $(\%)\left(60^{\circ} \mathrm{C}, 30\right.$ days $)$} \\
\cline { 2 - 5 } & Fenpropathrin $^{\mathrm{a})}$ & Malathion $^{\mathrm{a})}$ & Cypermethrin $^{\mathrm{b})}$ & Malathion $^{\mathrm{b})}$ \\
\hline No addition & 39.3 & 21.1 & 36.5 & 20.9 \\
$5 \%$ of Na polyphosphate & 3.5 & 18.4 & 5.6 & 17.3 \\
$5 \%$ of calcium carbonate & 3.5 & 19.9 & 5.3 & 19.8 \\
\hline
\end{tabular}

a) A mixture of fenpropathrin and malathion.

b) A mixture of cypermethrin and malathion.

at the benzyl ester site of fenvalerate.

Contrary to potassium carbonate, calcium carbonate was able to stabilize fenvalerate without having any apparent effect on the stability of malathion. The difference in stabilization effect between potassium carbonate and calcium carbonate seemed to depend upon their alkalinity in mineral carriers. Calcium acetate, sodium borate, sodium phosphate, and sodium polyphosphate acted as stabilizers for fenvalerate without disturbing the stability of malathion to any significant extent. Table 4 also shows the effect of sodium polyphosphate and calcium carbonate on the stability of some $\alpha$-cyano-pyrethroids in the presence of malathion. These salts acted as effective stabilizers for the pyrethroids studied with very little effect on the stability of malathion.

\section{ACKNOWLEDGMENTS}

The authors wish to express their thanks to Mr. T. Nakaiso and Miss J. Tanaka for their assistance for the completion of this work. They are indebted to Sumitomo Chemical Co., Ltd., for its permission to publish this work.

\section{REFERENCES}

1) M. Elliott, A. W. Farnhum, N. F. Janes, P. H. Needham, D. A. Pulman \& J. H. Stevenson: Nature (London) 246, 169 (1973)

2) R. D. O'Brien: World Rev. Pest Control 1, 29 (1962)

3) C. J. Lloyd \& G. E. Ruczkowski: Pestic. Sci. 11, 331 (1980)

4) J. L. Robertson \& K. C. Smith: J. Econ.
Entomol. 77, 19 (1984)

5) A. K. Halder, V. K. Srivastava, M. L. Maheshwari \& B. S. Parmer: Int. J. Trop. Agric. 1, 75 (1983)

6) A. K. Halder \& B. S. Parmer: J. Pesticide Sci. 9, 147 (1984)

7) V. Migrdichian: "The Chemistry of Organic Cyanogen Compounds," Reinhold, New York, p. 84, 1947

8) W. Autenrieth \& H. Brüning: Berichte $\mathbf{3 6}$, 3464 (1903)

9) R. Rogers \& D. G. Neilson: Chem. Rev. 61, 179 (1961)

10) Y. Katayama \& F. Horide (Sumitomo Chemical Co., Ltd.): PCT/JP 88/252, March 10 (1988)

要約

\section{マラチオン存在下における $\boldsymbol{\alpha}$-シアノベンジル エステル系ピレスロイドの鉱物質担体中での安 定性}

片山泰之, 堀出文男, 辻 孝三 各種ピレスロイドの鉱物質担体中での安定性を，マラ チオンが存在する場合，打よびしない場合について検討 した、マラチオンが存在しない場合, すべてのピレスロ イドは安定であった，マラチオンが存在する場合は，分 子中にシアノ基を有するピレスロイドのみ分解が認めら れた．この分解の原因はピレスロイドのシアノ基とマラ チオン分解物である酸性物質との反応によるものと思わ れた. 各種スペクトルの解析の結果, ピレスロイドのシ アノ基は (メチルチオ) カルボニル基に変換されたもの と推定された。炭酸カルシウム, リン酸ナトリウム等の 弱酸塩の添加はマラチオンの安定性に影響することなく ピレスロイドの分解を著しく軽隇することがわかった。 